\title{
Variation of Drinking Water Quality in Rural Areas of Kurunegala District, Sri Lanka
}

\author{
KAKA Samarasinghe ${ }^{1}$, MB Samarakoon ${ }^{2}$ \\ ${ }^{1}$ Department of Civil Engineering, General Sir John Kotelawala Defense University, Sri Lanka \\ Email: kavianuruddha90@gmail.com \\ ${ }^{2}$ Senior Lecturer, Department of Civil Engineering, General Sir John Kotelawala Defense University, Sri Lanka \\ Email: methsiris@gmail.com
}

\begin{abstract}
Due to the human activities, the natural water system gets contaminated with various chemical substances which can be harmful for the human health. In this research, it was attempted to find out the variation of drinkingwater quality in rural areas of Kurunegala district, Sri Lanka. Five GramaNiladari (GN) divisions in Ibbagamuwa Divisional Secretariat (DS) Division, were selected as the study area for this research. Seven water quality parameters were investigated in laboratory scale, which were basically divided in to physical and chemical parameters. Altogether 150 samples were collectedand all the parameters were investigated in the laboratory scaleunder the standard specifications given in SLS 614:2013 part 1 .
\end{abstract}

In this research, it was identified that Ibbagamuwa DS Divisionwas badly contaminated with water hardness (exceeded the standard limit of $200 \mathrm{mg} / \mathrm{l}$ ). Further, several areas were identified as not suitable for drinking purposes. Most of the time, these unsuitable areas were reported around the Kibulwanaoya reservoir, one of the main irrigation reservoirs located inIbbagamuwa DS Division. This area was highly contaminated with chloride and fluoride iron. There were several places that were appropriately identified as safe for drinking purposes because all the water quality parameters in that area were within the standard limit. The areas with suitable water resources have been identified around the rocky areas. It was also identified that the ground water around the highly cultivated areas and irrigation reservoir were not in good condition.

The design of separate maps for each water quality parameters were very important for people in this area. By referring these maps, they will be able to identify what are the suitable and unsuitable areas to take water for the purpose of drinking.

Keywords-Ibbagamuwa Divisional Secretariat Division, North Western Province, Drinking water quality parameters, Kibulwanaoya Irrigation Reservoir.

\section{INTRODUCTION}

Water is the most considearable and valuable wealth for living beings. All the living beings are consuming water for their daily needs. Without having water, there is no existence of lives on planet. In Sri Lanka, most of the time, people use ground water sources as their source of water but in most of the urban areas, people use tap water as their source of water. Tap water is mainly supplied by the Water Board of Sri Lanka and few other relevant organizations.

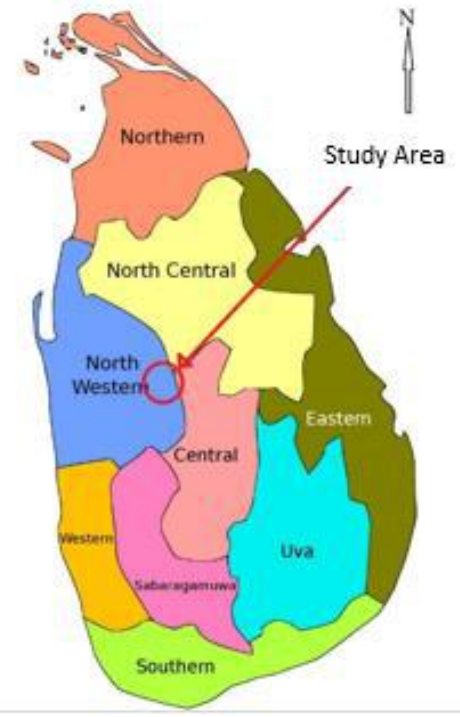

Fig. 1: Location of the selected Study Area

As for rural areas, most of the time people use well water for their daily drinking purposes. In this case, there might be a risk of water borne diseases because in Sri Lanka there is no any regulations or law to determine the quality of these ground water resources. As a result, many rural districts such as Anuradhapura, Polonnaruwa and Kurunagala etc. are highly affected by water borne diseases. Chronic kidney disease, renal disease, Dental fluorosis, Bladder stones are some of the drinking water related long term diseases. These diseases are very dangerous and the ultimateresult can be death. As an outcome of this research, proper solutions can be 
identified in order to safeguard people from these water borne diseases.

The purpose of this research is to identify the variation of drinking water quality in rural areas of Kurunegala District. Fig.1 shows the location of the selected study area. Five GN divisions in Ibbagamuwa DS Division were selected for this investigation of drinking water quality.

The following factors were considered when selecting Ibbagamuwa DS Division as the study area.

- Geographical location

- Population

- Educational standard of the people

- Ground soil condition

- Details of ground water aquifers

- Type of domestic water resources used

- Historical details of water related diseases in this area

The variation of drinking water quality in these five GramaNiladari divisions is discussed in this research. The main objective of this research is to collect information about the drinking water resources of this selected area. In this study area, people are mostly usingnatural water resources or dug wells as theirdrinking water resources as shown in

Table 1 . Therefore the investigation of drinking water in this area was mainly focused on well water.

Table 1 Main Source of Drinking Water in Rural Area

\begin{tabular}{|c|c|c|c|c|c|c|c|c|}
\hline \multirow[t]{3}{*}{ GN Division } & \multirow{3}{*}{$\begin{array}{c}\text { Number } \\
\text { of } \\
\text { Houses }\end{array}$} & \multicolumn{7}{|c|}{ Main Source of Drinking Water } \\
\hline & & \multicolumn{2}{|c|}{ Well } & \multirow{2}{*}{$\begin{array}{c}\text { Pipe } \\
\text { Borne } \\
\text { Water }\end{array}$} & \multirow{2}{*}{$\begin{array}{l}\text { Rural } \\
\text { Water }\end{array}$} & \multirow{2}{*}{$\begin{array}{l}\text { Tube } \\
\text { Well }\end{array}$} & \multirow{2}{*}{$\begin{array}{l}\text { Bottled } \\
\text { Water }\end{array}$} & \multirow[t]{2}{*}{ Other } \\
\hline & & $\begin{array}{c}\text { Protected } \\
\text { well }\end{array}$ & $\begin{array}{c}\text { Unprotected } \\
\text { Well }\end{array}$ & & & & & \\
\hline Neerammulla & 385 & 322 & 19 & 30 & 4 & 2 & - & 8 \\
\hline Leenawa & 224 & 223 & - & 1 & - & - & - & - \\
\hline Bandipola & 248 & 226 & 10 & 1 & - & 6 & - & 5 \\
\hline Pitapahamuna & 250 & 247 & 2 & - & - & 1 & - & - \\
\hline Karadagolla & 431 & 369 & 19 & 7 & 29 & 5 & - & 2 \\
\hline
\end{tabular}

\subsection{Drinking Water Quality and Water quality} standards in Sri Lanka

In this research seven water quality parameters were checked in laboratory scale. To determine the selected water quality parameters, the Environmental Laboratory of the General Sir John KotelawalaDefence University was used.These selected parameters were divided in to two different categories, which are physical and chemical parameters. According to the physical characteristics of the drinking water, three main parameters were discussed as follows.

- Colour (Hazen Unit).

- Turbidity (NTU).

- $\mathrm{pH}$ at $250 \mathrm{C}$.

According to the chemical characteristics of drinking water, four main parameters were discussed as follows.
- $\quad$ Chloride (as $\left.\mathrm{Cl}^{-}\right)$.

- Fluoride (as $\mathrm{F}^{-}$).

- Total Alkalinity (as $\mathrm{CaCO}_{3}$ ).

- Total Iron (as Fe).

Table. 2 shows the ranges and the maximum exceeding limit for each and every parameter.

Table.2: Standard specification requirements

\begin{tabular}{|l|c|}
\hline \multicolumn{1}{|c|}{ PARAMETER } & $\begin{array}{c}\text { Requirement } \\
\text { (SLS 614: 2013 } \\
\text { part 1) }\end{array}$ \\
\hline \multicolumn{2}{|l|}{ A.Physical-Organoleptic Requirements } \\
\hline Colour, Hazen Units, (max.) & 15 \\
\hline $\begin{array}{l}\text { Turbidity, (NTU) (Nephelometric } \\
\text { Turbidity Units), (max.) }\end{array}$ & 2 \\
\hline $\mathrm{pH}$ at $25^{0} \mathrm{C}+.2^{0} \mathrm{C}$ & 6.5 to 8.5 \\
\hline B. Chemical requirements \\
\hline Chloride $\left(\right.$ as $\left.\mathrm{Cl}^{-}\right)(\mathrm{mg} / \mathrm{l})$ & 250 \\
\hline Fluoride $\left(\right.$ as $\left.\mathrm{F}^{-}\right)(\mathrm{mg} / \mathrm{l})$ & 1.0 \\
\hline Iron $($ as $\mathrm{Fe})(\mathrm{mg} / \mathrm{l})$ & 0.3 \\
\hline Total alkalinity $\left(\right.$ as $\left.\mathrm{CaC} 0_{3}\right)(\mathrm{mg} / \mathrm{l})$ & 200 \\
\hline
\end{tabular}

All these parameters were investigated under the standard specifications of SLS 614: 2013 part 1 and the Drinking Water Standards which are followed by the National Water Supply and Drainage Board of Sri Lanka [1].These standards were carried out ensuring conformity to the provisions of the National Environmental Act and its regulations [7].

\section{METHODOLOGY}

This research is based on the experimental data analysis method. From the field investigation and the details collected from the statistic division of the Kurunegala district, it was found that most of the rural area people are consuming drinking water from dug wells [4]. Therefore this study was based on these dug wells of this particular area. Several types of dug wells were located in Ibbagamuwa DS division, such as tube wells, agro wells etc.

\subsection{Sampling}

150 Samples were collected from the five GN divisions in this Ibbagamuwa DS division. Nearly 30 samples were collected from each GN division. The sample locations were measured by using a Hand Heal GPS apparatus. A depth between $1 \mathrm{~m}$ to $12 \mathrm{~m}$ in shallow wells was selected and $175 \mathrm{ml}$ glass bottles were used to collect all the samples. Fig. 2 shows the sampling locations in the study area. 


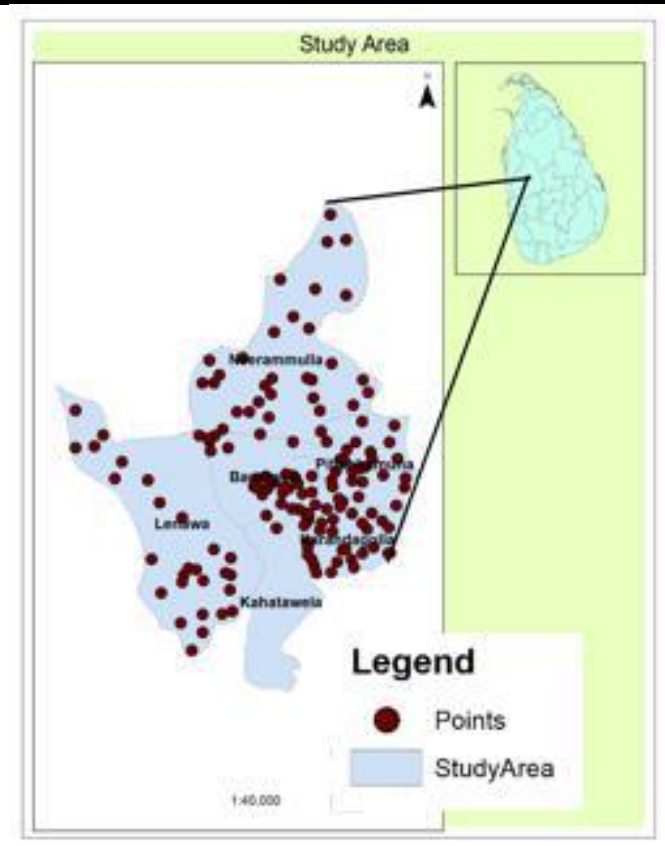

Fig. 2: Sampling locations in the study area

\subsection{Laboratory Experiment}

All the collected samples were stored in a thermo freezer under laboratory conditions. To determine the water quality parameters, the following apparatus were used as given in Table 3.

Table 3 Apparatus and specifications

\begin{tabular}{|l|l|l|}
\hline PARAMETER & APPRATUS & SERIAL NO \\
\hline $\begin{array}{l}\text { Colour, Hazen } \\
\text { Units }\end{array}$ & $\begin{array}{l}\text { UV Visible } \\
\text { Spectrophotomet } \\
\text { er (HACH } \\
\text { DR6000) }\end{array}$ & S/N1569293 \\
\hline Turbidity (NTU) & $\begin{array}{l}\text { Turbidimeter } \\
\text { Model 2100N }\end{array}$ & S/N14010C0310 \\
\hline $\begin{array}{l}\text { pH at } 25^{0} \mathrm{C}+- \\
2^{0} \mathrm{C}\end{array}$ & $\begin{array}{l}\text { HI 2111 pH/ORP } \\
\text { Meter }\end{array}$ & S/N08702309 \\
\hline $\begin{array}{l}\left.\text { Chloride (as } \mathrm{Cl}^{-}\right) \\
(\mathrm{mg} / \mathrm{l})\end{array}$ & $\begin{array}{l}\text { Digital Titration } \\
\text { Apparatus }\end{array}$ & 16900 \\
\hline $\begin{array}{l}\text { Fluoride }\left(\text { as } \mathrm{F}^{-}\right) \\
(\mathrm{mg} / \mathrm{l})\end{array}$ & $\begin{array}{l}\text { Digital Titration } \\
\text { Apparatus }\end{array}$ & 16900 \\
\hline $\begin{array}{l}\text { Total alkalinity } \\
(\text { as CaCO } \\
\text { (mg/l) }\end{array}$ & $\begin{array}{l}\text { Digital Titration } \\
\text { Apparatus }\end{array}$ & 16900 \\
\hline $\begin{array}{l}\text { Iron (as Fe) } \\
(\mathrm{mg} / \mathrm{l})\end{array}$ & $\begin{array}{l}\text { Spectrophotomet } \\
\text { er (HACH } \\
\text { DR6000) }\end{array}$ & S/N1569293 \\
\hline
\end{tabular}

All the samples were investigated according to the standards and specifications given by the company. All the experiments were carried out under the room temperature.

After this, tested data were put in to a proper excel worksheet. This worksheet include all the physical and chemical parameters which were tested in the laboratory and the number of samples.

\subsection{Data Analysis Using Arc GIS Model.}

Basically IDW (Inverse Distance Weight) method was used for this analytical part. By using this IDW method, all the samples were reclassified from the exact range. Then the sample points were interpolated to determine all the surface details of the particular data set. All the physical and chemical characteristics were used to design a unique map. The design model is shown inFig. 3.

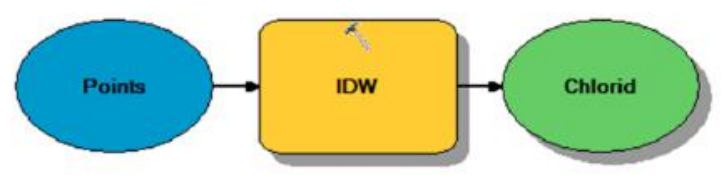

Fig. 3: Model of IDW

The selected study area consists of a main irrigation reservoir and few other small scale streams and lakes. Ground water characteristics of this particular area are not included in this research range. In this Arc GIS map designed for the surface water area,the interpolation values of this surface water resources might not be correct. Therefore it was assumed,that these surface water resources might consist the same ground water table for this IDW interpolation method.

\section{RESULTS AND DISCUSSION}

\subsection{Physical characteristics}

To determine the physical characteristic of drinking water there are several types of test procedures to follow.

\subsubsection{Variation of colour (Hazen Unit)}

A simple colorimetric procedure was developed for apparent color determinations using platinum cobalt standards and expressing the results in Hazen units. The method involves measuring the absorbance of a sample with a colorimeter using two broad band fillers. A second absorbance reading is required to obtain a suitable correction for particulates. With this method, the human response factor is minimized, and the accuracy, as estimated by standard deviation, is one Hazen unit [3]. 


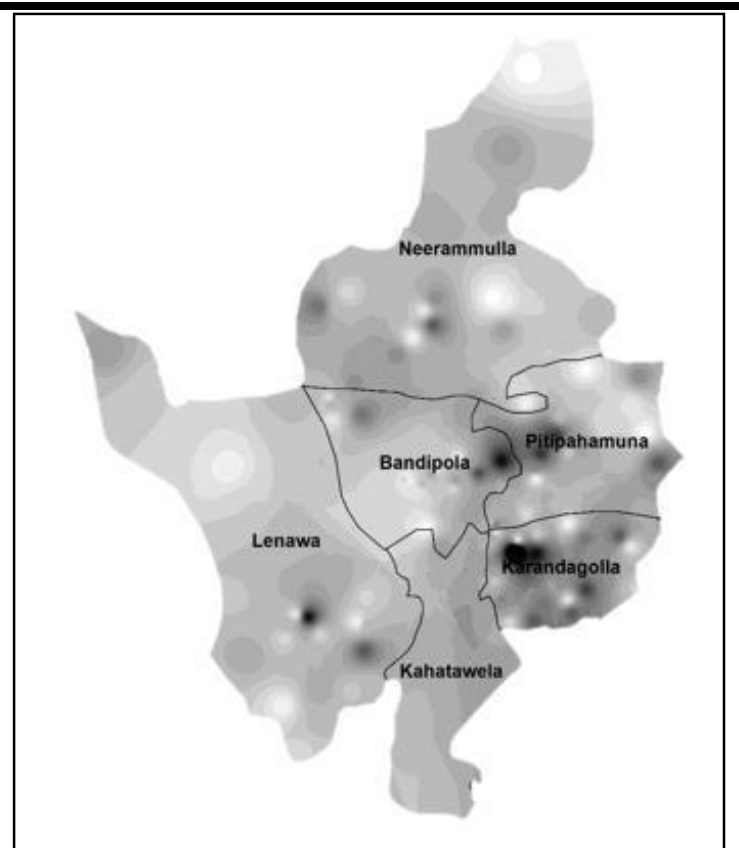

Fig. 4: Variation of colour in Pitipahamuna, Bandipola, Leenawa, Neerammulla and Karadagolla GN Divisions 2017

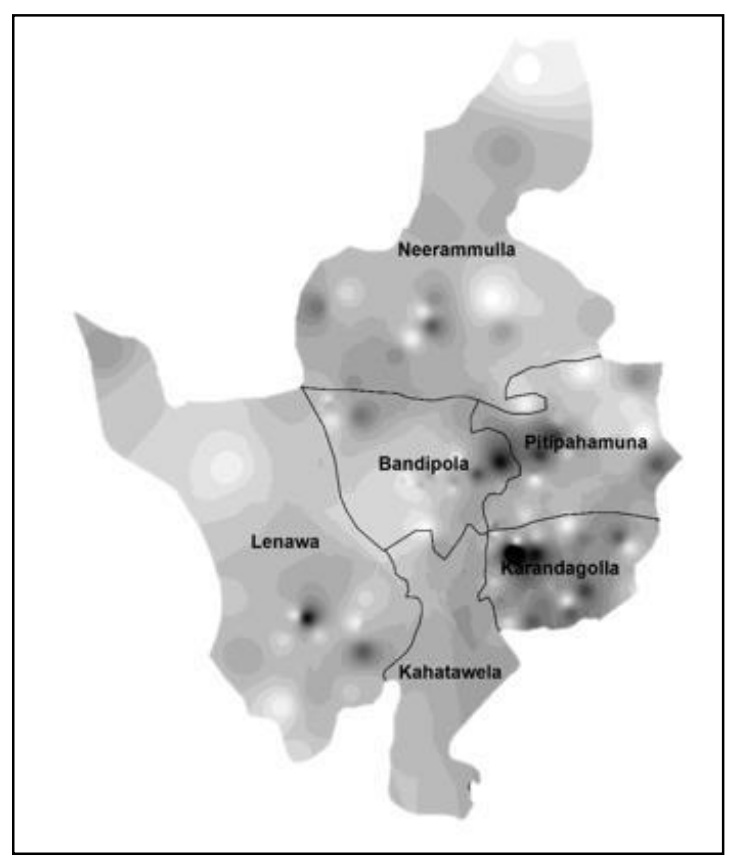

Fig. 4shows the variation of colour in this five GN divisions by using separate colour variation of White to

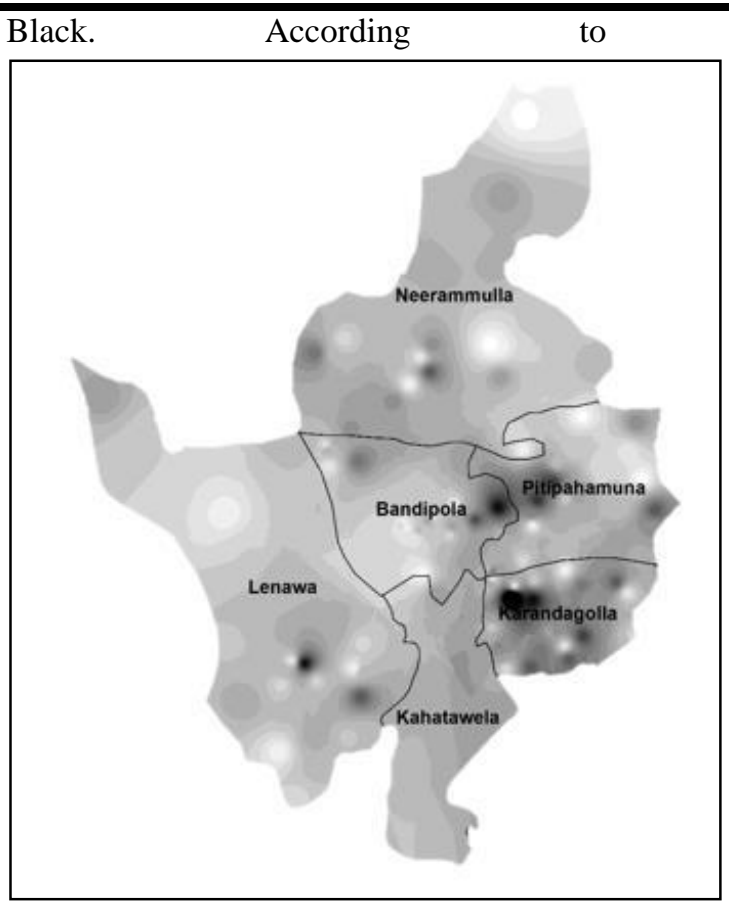

Fig. 4 the black colour represents the area where the colour has exceeded its limit, and grey and white colours represent the safe levels of the drinking water in colour. One Hazen unit represents a specified colour range. 0 to 1 represent white colour, 1 to 2 represent another different colour. According to the results of this study area, no any sample has exceeded the maximum range of colour [3].

\subsubsection{Variation of Turbidity (NTU)}

The definition of Turbidity is the cloudy appearance of a fluid caused by suspended solids that are usually invisible to the normal eye. It is also called as an aggregate optical property of the water and does not identify individual substances. There are several ways to determine turbidity in water. The most commonly used method is the measure of attenuation, or reduction in strength and a light source, as it passes through a water sample. NephelometricTurbidity Units (NTU) are the units of measurement used by a nephelometer meeting EPA design criteria [2]. 


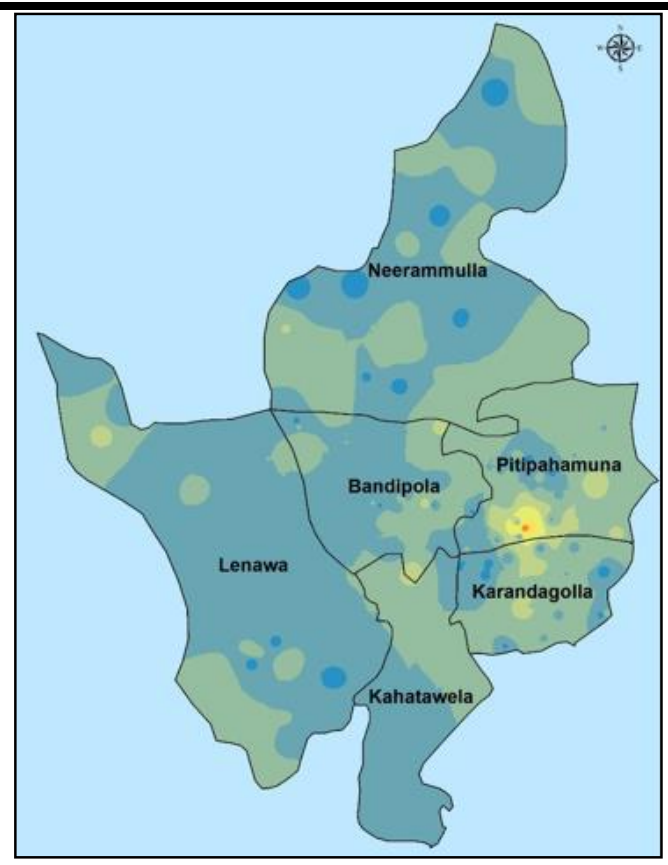

Fig. 5: Variation of Turbidity in Pitipahamuna, Bandipola, Leenawa, Neerammulla and Karadagolla GN Divisions 2017

As shown in

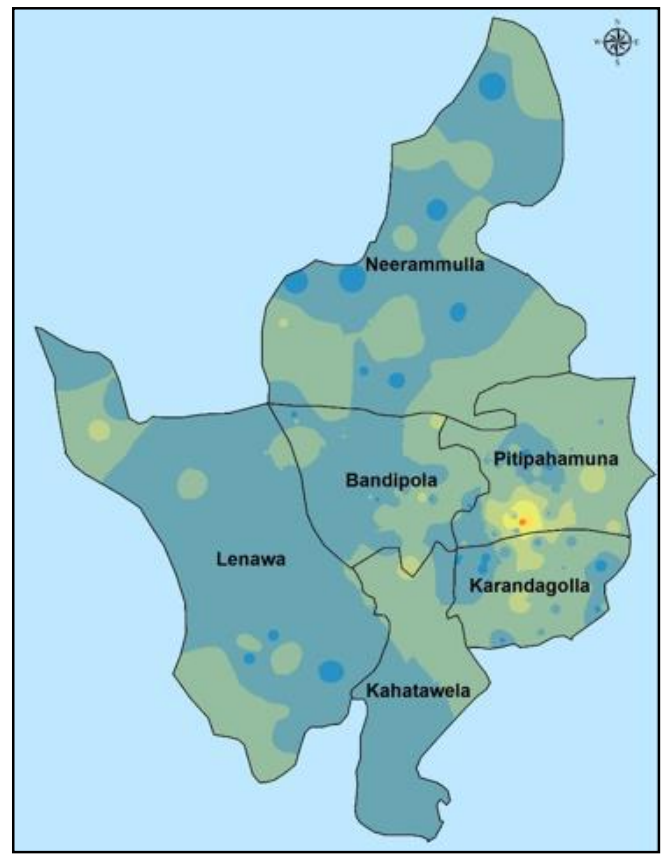

Fig. 5, variation of turbidity were represented by using separate colour range. Basically the Turbidity value in drinking water may vary in this selected area in a range of 0 to 2 NTU. The variation of Turbidity was represented in a colour range of Blue Colour to Yellow colour. But according to the test result carried out in KDU laboratory, there were no any sample reported in the exceeded limit of turbidity. Therefore all the values which were included in this map were in safe range for drinking water.

\subsubsection{Variation of $\mathrm{pH}$ at $25^{\circ} \mathrm{C}+/ 2^{0} \mathrm{C}$}

Basically the $\mathrm{pH}$ value is a good indicator to identify whether water is hard or soft. The $\mathrm{pH}$ value of pure water is 7. In general, water with a $\mathrm{pH}$ lower than 7 is considered acidic, and with a $\mathrm{pH}$ greater than 7 is considered basic. The normal range for $\mathrm{pH}$ in surface water systems is 6.5 to 8.5 , and the $\mathrm{pH}$ range for groundwater systems is in between 6 to 8.5 [5]. The measurement of $\mathrm{pH}$ was carried out at the room temperature of $25^{\circ} \mathrm{C}+{ }_{-} 2^{0} \mathrm{C}$.

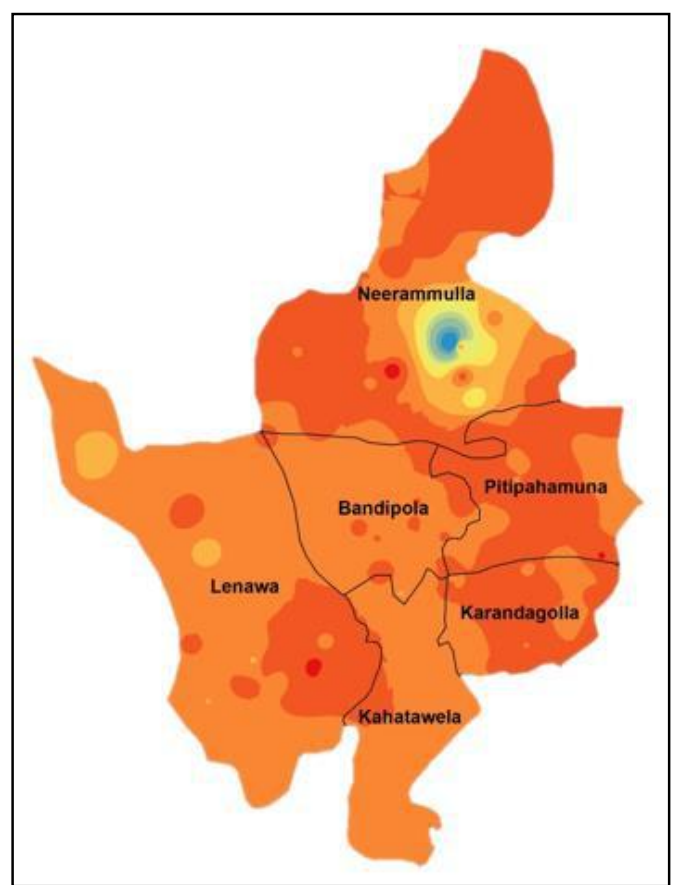

Fig. 6: Variation of pH at 250C in Pitipahamuna, Bandipola, Leenawa, Neerammulla and Karadagolla GN Divisions 2017

According to 


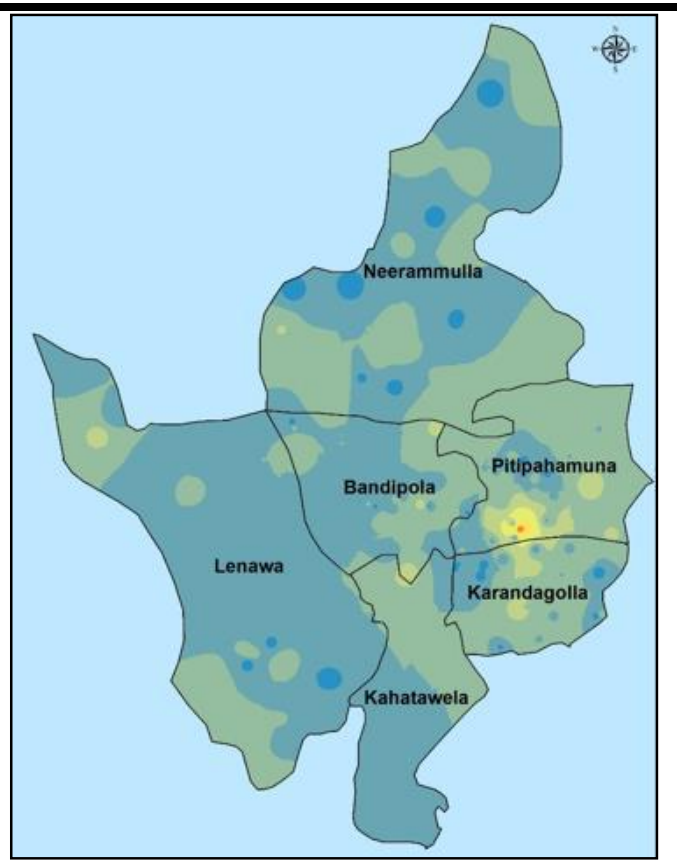

Fig. 5 there were several cases where the $\mathrm{pH}$ value is low. But these values were not below the minimum value of $\mathrm{pH}$ according to the standard specifications. By referring this map it can be easily identified what are the vulnerable areas in variation of $\mathrm{pH}$ value.

\subsection{Chemical Characteristics}

Distilled water is considered as pure water that is not contaminated with any kind of suspended particles or chemical substances. The chemical substances in the ground surface are diluted in ground water. Rain and surface runoff directly causethe contamination of heavy metals in ground water, as this surface runoff water passes through the cultivated lands in this area. These cultivated lands consists of a high percentage of heavy metals, because the farmers use poison and inorganic fertilizers for their cultivations. Another important parameter to understand the contamination of chemical substances in ground water is, the surface and ground soil condition in this area.

\subsubsection{Variation of Chloride $(\mathrm{mg} / \mathrm{l})$}

Chloride can be found in ground water as diluted salts such as Sodium Chloride $(\mathrm{NaCl})$, Potassium Chloride $(\mathrm{KCl})$, and Calcium Chloride $\left(\mathrm{CaCl}_{2}\right)$. Chloride can be found in surface and ground water generated from both natural and anthropogenic sources, such as run-off containing road de-icing salts, use of organic fertilizers, landfill leachates, septic tank influents, animal feeds, industrial influent and irrigation drainage[1]. Chloride can also enter a watershed through water softener discharge or sewage contamination. Another important anthropogenic source of chloride in ground water is, fertilizer made with potash, or mined salts. Potassium Chloride $(\mathrm{KCl})$ is the salt most commonly used in potash fertilizer. However, this potash can leach from fertilizer soil to the rivers and streams. Ultimately these chlorides are collected to natural water bodies and diluted ground water sources [6].

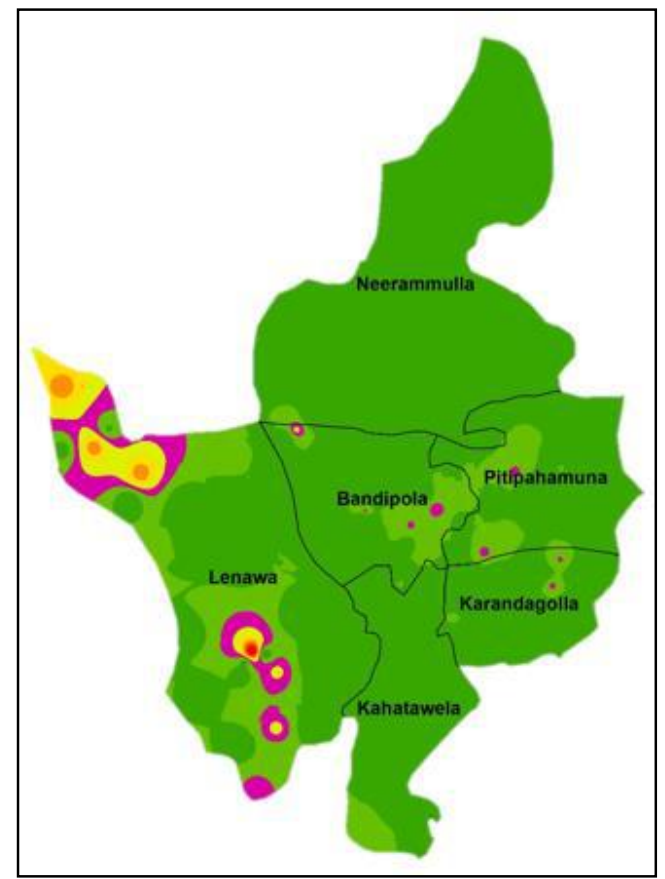

Fig. 7: Variation of Chloride in Pitipahamuna, Bandipola, Leenawa, Neerammulla and Karadagolla GN Divisions 2017

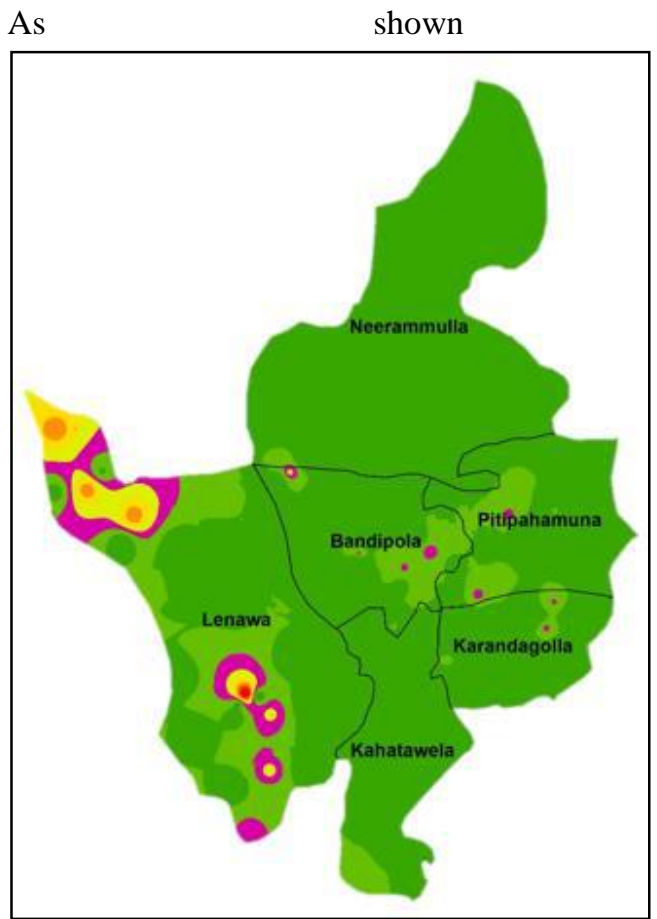

Fig. 7,the variation of chloride were represented in separate colour ranges. Minimum value of chloride is shown in green colour and maximum chloride ranges were shown in red colour. Purple and yellow colour represent the exceeded values of chloride. Neerammulla GN division was considered as safe for drinking water in 


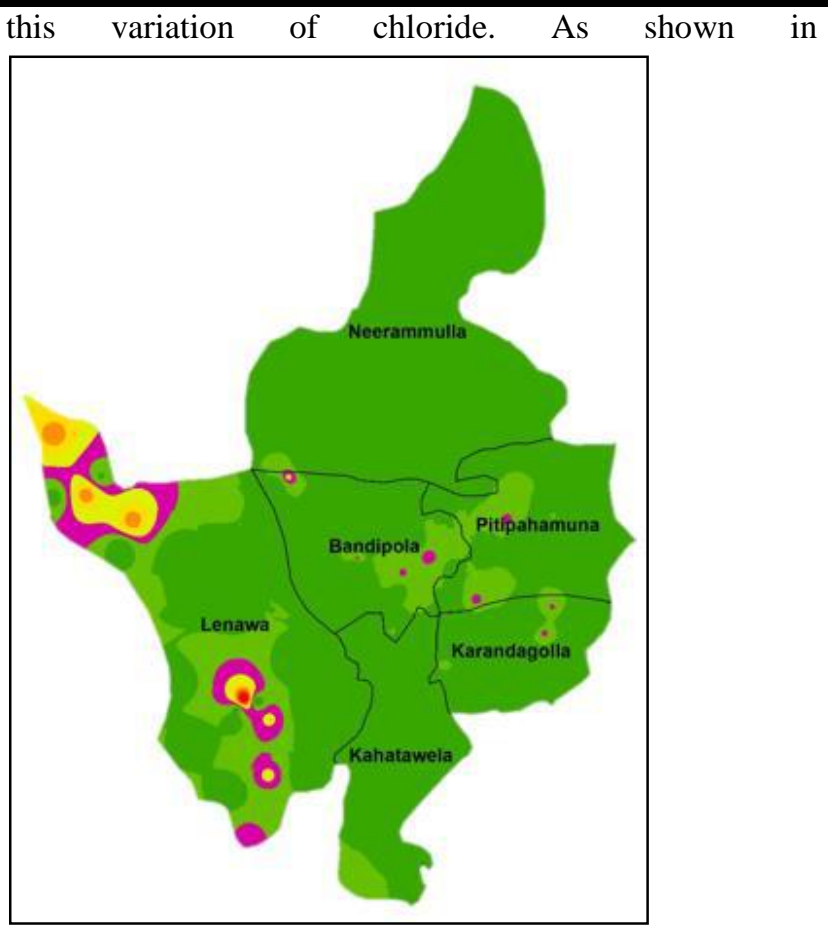

Fig. 7 all other four GN divisions were having some issues in chloride.

\subsubsection{Variation of Total Alkalinity (mg/l)}

Alkalinity of drinking water may be due to the presence of irons. Hydroxides, carbonates and bicarbonates are the iron that case of this alkalinity. Alkalinity of water may be defined as its capacity to neutralize acid. Alkyl substances in water include hydroxide or bases. Most of the times alkalinity of surface and ground water comes from calcium carbonate $\left(\mathrm{CaCO}_{3}\right)$ generated from rock and soil. This process is enhanced if the rocks and soil have already been broken up before entering the water. When discussing the health effect of alkalinity in drinking water, it causes excessive drying of the skin due to the fact that they tend to remove normal skin oil. Actually this can be happened when high mineralized alkaline is present in water.

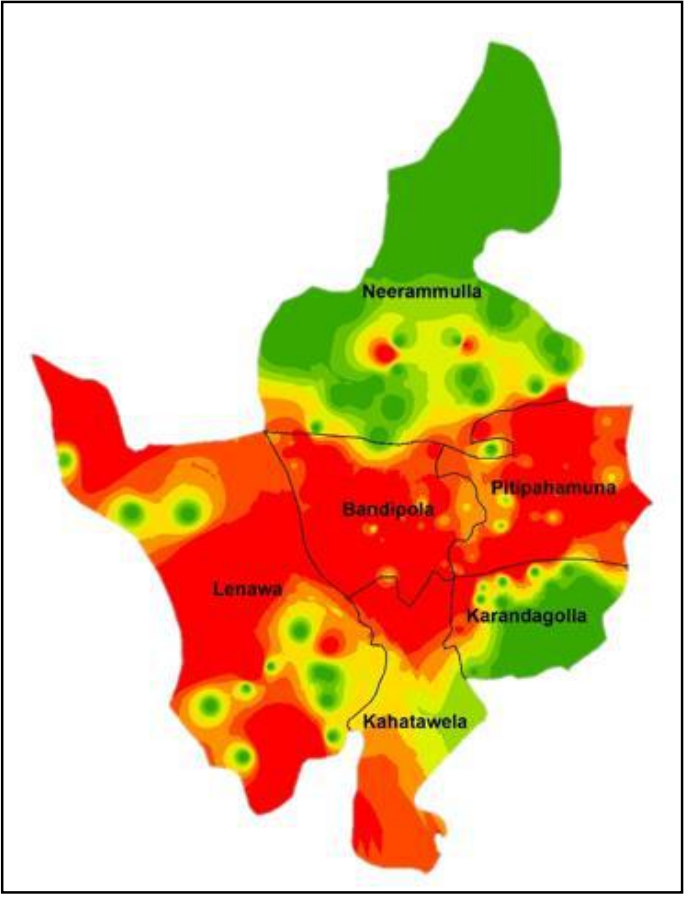

Fig. 8: Variation of Total Alkalinity in Pitipahamuna, Bandipola, Leenawa, Neerammulla and Karadagolla GN Divisions 2017

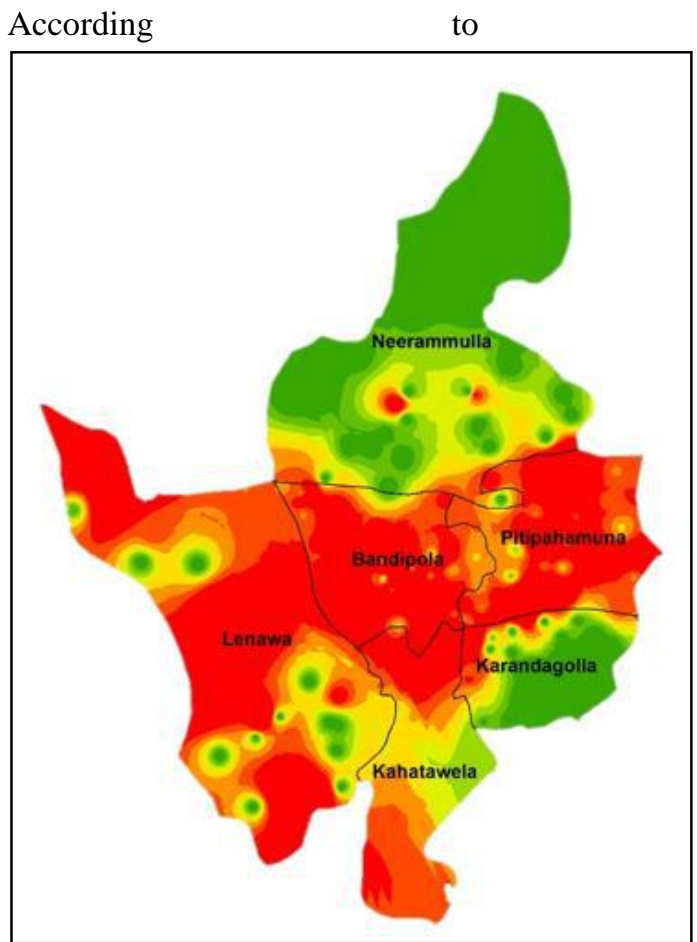

Fig. 8 total alkalinity of this study area was represented in a separatecolour range. Safe drinking water zone was represent in the range of green to yellow and unsafe drinking water zone was represented in dark yellow to red 


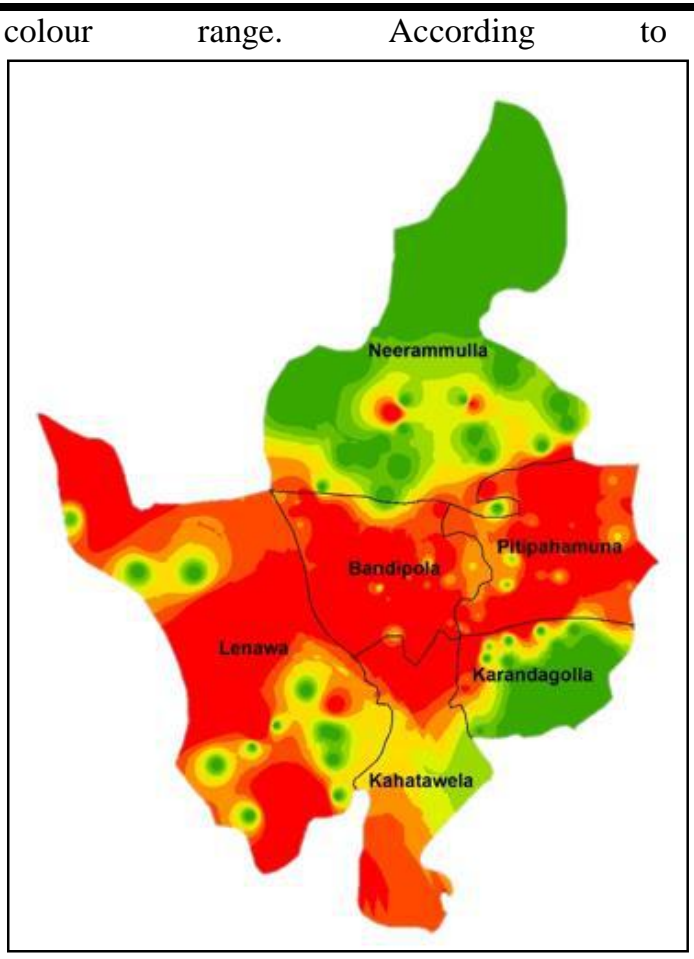

Fig. 8 the variation of total alkalinity in this study area were highly contaminated with $\mathrm{CO}^{3-}$ and $\mathrm{HCO}^{3-}$-ions [8]. On the other hand, it was concluded that this area were highly contaminated with $\mathrm{CaCO}_{3}$ or $\mathrm{MgCO}_{3}$ crystalline. By referring this map it was clearly identified that Pitipahamuna, Bandipola, Karadagolla and Leenawa GN divisions were considered as highly contaminatedby hardness (exceeded the maximum standard limit of 200 $\mathrm{mg} / \mathrm{l})$. Therefore, people who refer this map would be able to identify the unsafe drinking water resources easily.

\subsubsection{Variation of Fluoride $(\mathrm{mg} / \mathrm{l})$.}

Fluoride can be considered as an essential iron for human health. But when fluoride ingested in excessive dose it becomes toxic. Low fluoride in water also causes dental fluorosis which is very common in Central province and North Central province in Sri Lanka. The geochemical pathways of fluoride is strongly influenced by the process involving absorption-desorption and dissolution precipitation reactions [5]. Therefore, fluoride concentration of water mainly depends on the degree of weathering and the amount of leachable fluoride.

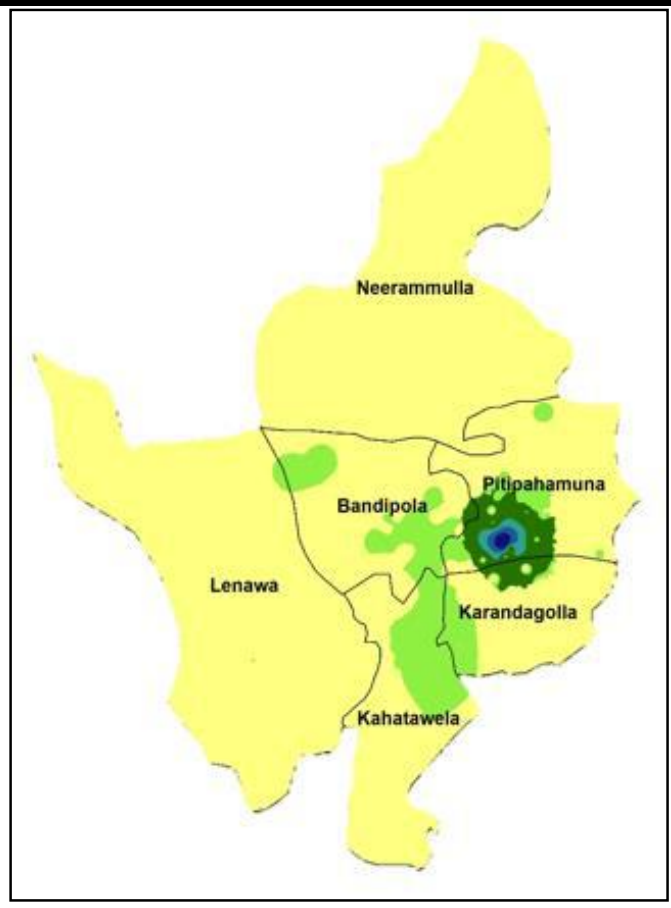

Fig. 9: Variation of Fluoride in Pitipahamuna, Bandipola, Leenawa, Neerammulla and Karadagolla GN Divisions 2017

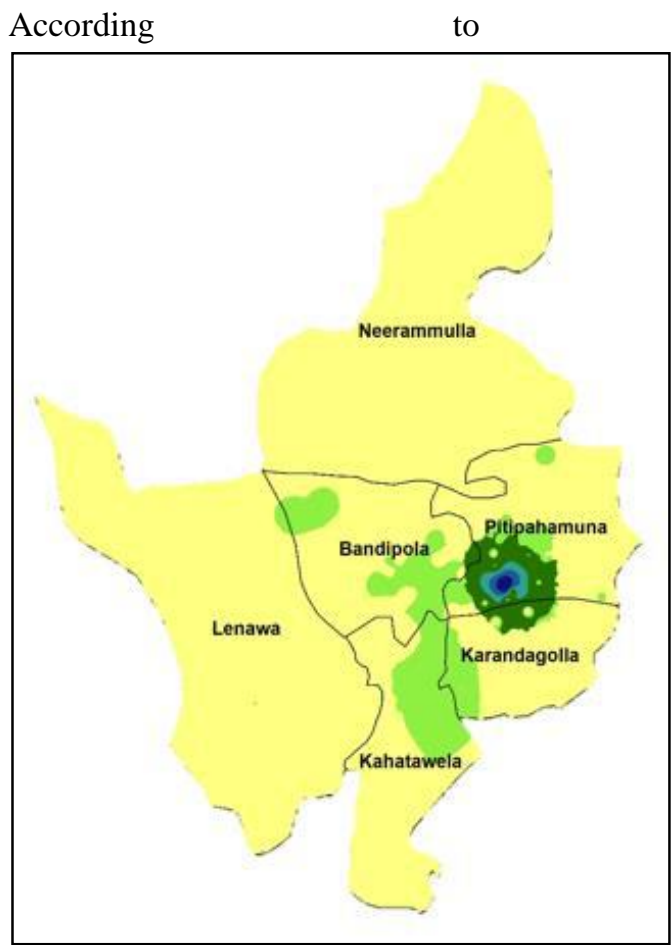

Fig. 9, the variation of fluoride in this study area was represented in a separate colour range. The accepted fluoride ranges were represented in yellow and light green colour and the exceeded ranges were represented in other colours. Pitapahamua GN division is having an unexpected fluoride variation of $49 \mathrm{mg} / \mathrm{l}$ as shown in Fig 9. 


\subsubsection{Variation of Total Iron $(\mathrm{mg} / \mathrm{l})$}

Mainly Iron can control the taste of the drinking water, asIron can produce Humic acids and that exert a positive influence in the presence of Fe Iron in drinking water. The Iron in water is basically in the form of $\mathrm{Fe}^{2+}$ which can occur largely under anoxic condition. It has been shown that $\mathrm{Fe}^{3+}$ is the only oxidation state which is possible for Iron in oxygen containing water such as domestic water. These forms can be reduced to the soluble $\mathrm{Fe}^{2+}$ Ions only under anoxic condition. Further, the oxidation of $\mathrm{Fe}^{2+}$ may also be catalyzed by a wide range of micro - organisms [1].

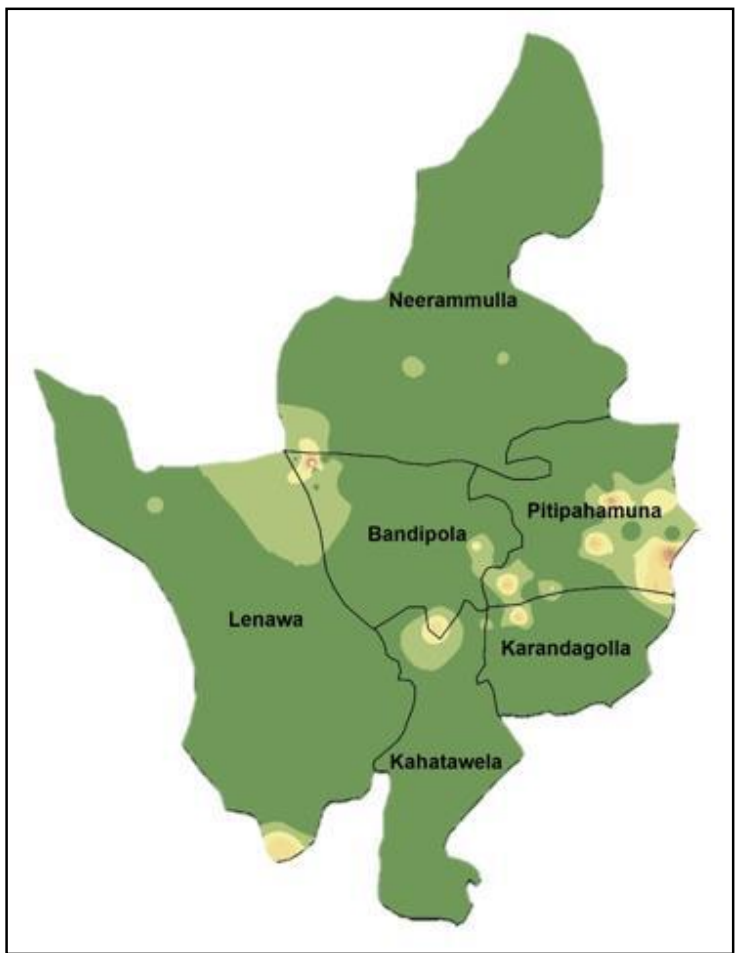

Fig. 10: Variation of Total Iron in Ptapahamuna,

Bandipola, Leenawa, Neerammulla and Karadagolla GN Divisions 2017

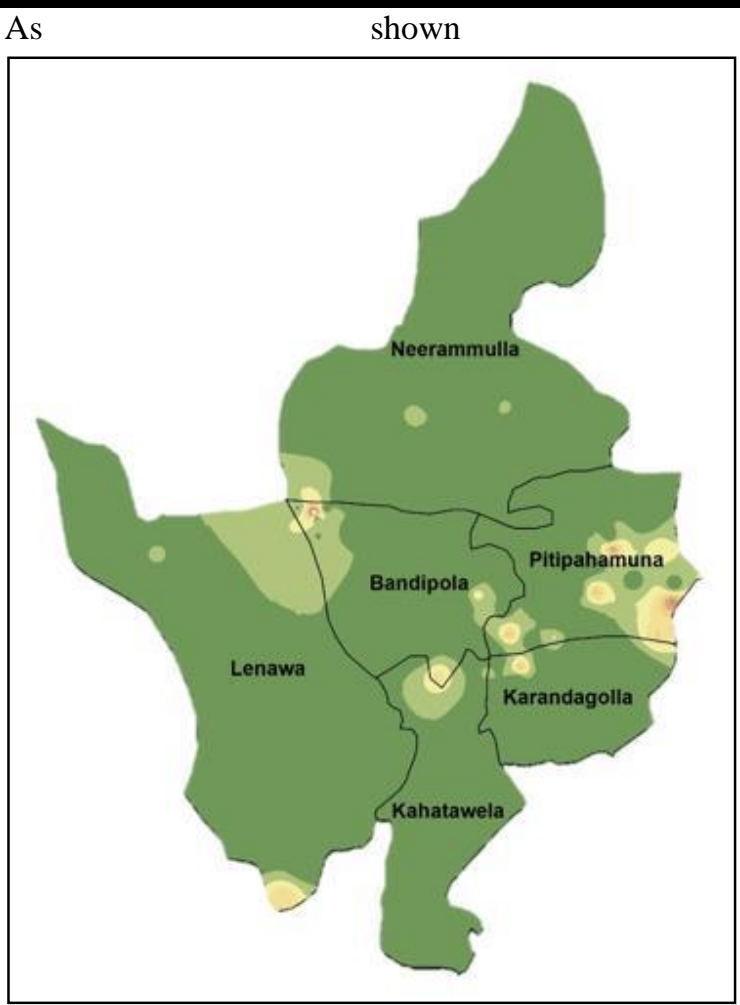

Fig. 10, the variation of total iron in this study area was represented in a separatecolour range. The acceptable total iron ranges were represented in green and light yellow colours. Except for these two colours, other colours represent the exceeded limit of total iron values. According to the

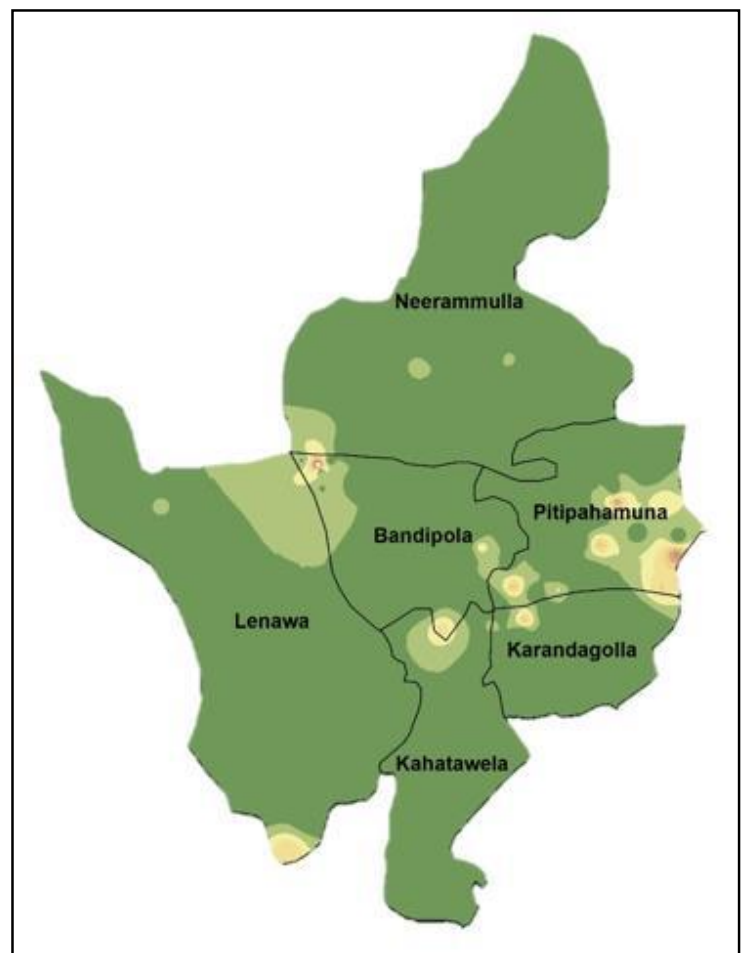

Fig. 10, the vulnerable and suitable areas for drinking water can be identified by considering the total iron concentration of water. 


\section{CONCLUSION}

According to these different types of maps which were designedto represent the variation of drinking water quality in this study area, the suitable and unsuitable areas for drinking water can be clearly identified. Especially in highly cultivated areas and reservoirs areas, ground water is not suitable for drinking purposes as both chloride and fluoride values in these areas have exceeded the maximum requirement according to the standard specifications. Few samples out of the 150 samples of drinking water was having heavy hardness in this study area. All these values have exceeded the maximum requirement of $200 \mathrm{mg} / \mathrm{l}$ according to the standard specifications of SLS: 614-2013 part 1. There were several locations which were identified as safe for drinking water. All the physical and chemical parameters were in between the standard range and below the maximum exceeded limit.

Ultimately it can be concluded that Ibbagamuwa DS division was badly contaminated with the total alkalinity. In the other hand the research area was contaminated with $\mathrm{Ca}^{2+}$ or $\mathrm{Mg}^{2+}$ irons. But except for the total alkalinity, these areascan be recommended for drinking purposes. To minimize the total alkalinity it was recommended to boil the water before use.

\section{ACKNOWLEDGEMENTS}

We take this opportunity to express our gratitude to the Department of Civil Engineering of General Sir John Kotelawala Defense University and National Water Supply and Drainage Board Sri Lanka for providing all the laboratory facilities and valuable instructions.

\section{REFERENCES}

[1] Amara Paranagama, Niranjali Jayasuriya, Muhammed A. Bhuiyan. 2013. "WATER QUALITY PARAMETERS IN RELATION TO ." Peradeniya.

[2] Company, H., 2013. Model 2100N Laborotory Turbidimeter Instruction Manual. 25 ed. Colarado: Hach Company.

[3] Crowther J, Evans J. 1981. "Estimating color in Hazen units by spectrophotometry." American Water Works Association 73 (6): 270.

[4] Dissanayake, C.B. 2005. "UNESCO and Ministry of Agriculture, Irrigation and Mahaweli Development." 33(3): 168.

[5] Emmanule, V.J. 2006. AHAnd Book For Applied Sanitary Engineering.Investment, Board of. 2011. "Envirnmental Norms." 24. Colombo: Board of Investment.

[6] Imbulana, K.A.U.S.,Wijesekera, N.T.S., Neupane, B.R., 2006. Sri Lanka National, Colombo: UNESCO and Ministry of Agriculture, Irrigation and Mahaweli Development.

[7] Investment, B. o., 2011. Envirnmental Norms. In: Colombo: Board of Investment, p. 24.

[8] Kikuchi, M., Weligamage, P., Barker, R., Samad, M.,Kono, H., 2003. Agro-Well and Pump Diffusion in the Dry Zones of Sri Lanka, Colombo: International Water Management Institute. 